\title{
通風時の流入開口部における圧力損失機構に関する研究 \\ A STUDY ON PRESSURE LOSS MECHANISM IN THE INFLOW OPENINGS \\ OF CROSS-VENTILATION
}

\author{
遠藤智行*, 倉㴊 隆 **, 大場正昭 ${ }^{* * *}$, 赤嶺 嘉彦**** \\ Tomoyuki ENDO, Takashi KURABUCHI, Masaaki OHBA \\ and Yoshihiko AKAMINE
}

\begin{abstract}
Pressure loss mechanism at the inflow opening of Cross-Ventilation is studied by detailed analysis of LES results. Manipulation of energy transfer equation through inflow openings suggests that reduction of discharge coefficient should be originated from dynamic pressure in tangential direction and should be observed as increased static pressure at the opening. Analysis of virtual stream tube reveals that the static pressure at the opening is transferred to dynamic pressure as 'vena contracta' in part and the remaining static pressure is dissipated as generation of turbulent kinetic energy.
\end{abstract}

Keywords : LES, Cross-ventilation, Local dynamic similarity model, Discharge coefficient, Vena contracta, Stream tube LES，通風，局所相似モデル，流量係数，縮流，流管

\section{1. はじめに}

近年、地球温暖化対策として、夏期の早朝や夜間、中間期に通風 を積極的に取り入れる気運が高まっている。これは、通風による建 物躯体の泠却や室内の温熱環境改善により、居住者の冷涼感と共に 冷房エネルギーの削減効果を期待しているものであり、通風を利用 した省エネルギー効果の試算を行なった研究も見られるようになっ ている。これらの検討には換気回路網計算による通風量を用いられ る事が一般的であるが、通風量算出過程において境界条件となる風 圧係数と流量係数の設定精度について言及している研究はほとんど 見られない。例えば、羽原ら 23) は屋外気流の CFD 計算を実施し、 風圧係数は風向角度毎の数值を設定しているが、流量係数は屋外気 流条件によらず、開口毎に一定值を用いて通風量を計算している。 風圧係数は近年の CFD 技術の向上により、比較的高い精度を持っ て、事前計算によって取得する事が可能となっている ${ }^{4) 566)}$ 。開口部 通過時の圧力損失係数や流量係数については、石原 7 、甲谷・山中 ら ${ }^{8)}$ による干渉係数の概念に関する研究や、勝田・関根ら 9)、清田・ 関根 ${ }^{10)}$ らによる開口部圧力損失係数に関する実験的研究、村上ら ${ }^{11)}$ によるエネルギー輸送量と通風量の関係に関する研究、小林 - 甲谷 ら 12)13)による建物周辺及び流管のエネルギー解析による研究などが 行なわれているが、開口部通過時に生じる圧力損失に起因する流量 係数変化のメカニズムは明らかにされていない。これに対し、筆者 らは既発表論文 14)15)において、開口部周辺の圧力場の様相から、気 流の力学的相似性に着目した局所相似モデルを提案した。本モデル
では、無次元室内圧 $\mathrm{P}_{\mathrm{R}}{ }^{*}$ という概念を新たに導入し、 $\mathrm{P}_{\mathrm{R}}{ }^{*}$ が同一とな る環境下においては、開口部周辺の気流場は局所的に力学的相似と なり、流量係数や流入角は $\mathrm{P}_{\mathrm{R}}{ }^{*} に よ り 一$ 意に決定されることを示し ている。また、筆者らは既発表論文 ${ }^{16)}$ において、流量係数と $\mathrm{P}_{\mathrm{R}}{ }^{*}$ と の関係式を構築し、式の導出に必要なパラメータ取得のための通気 性能評価法の開発を行ない、代表的な開口部形状における関係式を 公開している。その結果、多くの開口形状において、流量係数が大 きく変動するのは、換気駆動力に対して、開口部接線方向の動圧が 相対的に大きい| $\mathrm{P}_{\mathrm{R}}{ }^{*} \mid<5$ の領域であることを示し、現場実測の結 果から、 $\mathrm{P}_{\mathrm{R}}{ }^{*}$ がこの領域となるのは実在の戸建住宅で $60 \%$ 程度と比

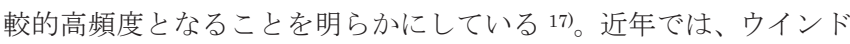
キャッチャーの利用や天空の通風利用等、様々な開口部形態が用い られ始めており、設計時における通風量の算出のためには、これら の開口部における流量係数変化を把握することも必要になると考え られる。このように、通風量のより高精度な算出のためには、流量 係数が変化するメカニズムの把握が必要となる。本研究では、通気 性能評価法 16)を模した計算モデルの構築を行い、単純形状の開口部 を対象とした LES 計算を実施し、流入開口部周辺の気流性状及び 仮想流管の解析結果から、流量係数変化のメカニズムと流入気流の エネルギー変化について考察を行う。

\section{1 局所相似モデルについて}

\section{2. 研究概要}

\footnotetext{
* 関東学院大学建築 · 環境学部建築 · 環境学科 准教授 $\cdot$ 博士 $($ 工学 $)$

** 東京理科大学工学部建築学科 教授・博士 (工学)

*** 東京工芸大学工学部建築学科 名誉教授. 工博

**** 国土交通省国土技術政策総合研究所 主任研究官・博士 (工学)
}

Assoc. Prof., Kanto Gakuin University, Dr.Eng.

Prof., Tokyo University of Science, Dr.Eng.

Emeritus Prof., Tokyo Polytechnic University, Dr.Eng.

Senior Research Officer, National Institute for Land and Infrastructure Management, Dr.Eng. 
検討に先立って、本研究に用いる局所相似モデルの概要について 説明する。Fig. 1 に流入開口部周辺の気流・圧力の様相について示 す。既往の結果5)によれば、通風気流は風向角や通風量によらずに、 アプローチフローの全圧 $\mathrm{P}_{\mathrm{T}}$ を概襍持したまま開口部へ到達する。 ここで、開口部接線方向動圧を $\mathrm{P}_{\mathrm{t}}$ 、開口部法線方向動圧を $\mathrm{P}_{\mathrm{n}}$ 、開口 部静圧を $\mathrm{P}_{\mathrm{s}}$ とおけば、全圧 $\mathrm{P}_{\mathrm{T}}$ は Table1 中の式 (1) で表わされる。 風圧 $\mathrm{P}_{\mathrm{W}}$ は開口部閉鎖時に、 $\mathrm{P}_{\mathrm{n}}$ が静圧転換されたものと考えられ、 開口部での $\mathrm{P}_{\mathrm{s}}$ との和として式（2）で表わされることから、 $\mathrm{P}_{\mathrm{t}}$ は式 （3）で表わ寸ことができる。通風は $\mathrm{P}_{\mathrm{W}}$ と室内圧 $\mathrm{P}_{\mathrm{R}}$ の差である換 気駆動力が発生することにより生じる。この $\mathrm{P}_{\mathrm{R}}$ を $\mathrm{P}_{\mathrm{W}}$ 基準で表わし た基準化室内圧を $\mathrm{P}_{\mathrm{r}}$ とし、式（4）で定義する。通風現象は $\mathrm{P}_{\mathrm{t}}$ の流 れにさらされた開口部に P r の大きさの換気駆動力が発生すること により生じることから、これらの比を無次元室内圧 $\mathrm{P}_{\mathrm{R}}{ }^{*}$ とし、式 (5) で定義する。また、流量係数を $\alpha$ 、流入角を $\beta$ とすると、それぞれ は式 (6)、（7）で表わすことが出来、通風量 $\mathrm{Q}$ は $\alpha$ と $\mathrm{P}$ r 老用いて、 式（8）のオリフィス式で求めることができる。開口部における力 学的相似が成立することから 15)16)、 $\mathrm{P}_{\mathrm{R}}{ }^{*}$ が一致する条件では開口部 周辺の動圧と圧力差の比が等しくなり、 $\alpha$ と $\beta$ は一意に決定される。 Fig.2 に示すように、 $\mathrm{P}_{\mathrm{R}}{ }^{*} 、 \alpha 、 \beta$ はそのいずれか一つが決まれば、 他は自動的に決定される。

\subsection{LES 計算概要}

通風性能評価実験 16)を模擬した Fig.3 に示寸風洞、開口部、チャ ンバーからなる空間を計算の対象とする注 2$)$ 。おお、本検討において は、風洞入口部の気流速度を代表速度、チャンバー短辺寸法を代表 長さとして無次元化した值で解析を行う。また、風洞内基準地点の 静圧を基準静圧とする。計算メッシュは、空間全体を $64 \times 35 \times 55$ に分割し、開口部は主流方向 14 メッシュ、スパン方向 9 メッシュ、 鉛直方向 4 メッシュで表現した。計算には $\mathrm{C}_{\mathrm{s}}=0.13$ とした Smagorinsky モデルを用いた。既往研究 5りおけるドライバー計算 のストックデータを主流方向の時間平均風速が鉛直方向に一様とな るよう加工した後、壁面近傍のデータを除去したものを風洞流入境 界条件として用いた注3)。また、Table2 に示寸無次元化された風量 を開口部面積 $(0.4 * 0.8)$ で除した值をチャンバー下部開口の法線方 向風速成分に設定することで、チャンバー上部開口（流入開口）で の通風現象を再現した。風洞の流出境界条件には対流型（移流型） 境界条件を用いた。壁面境界条件として、風洞床面及びチャンバー 内部にはカルマン三層モデルを適用し、風洞のその他の壁面につい ては、滑り境界条件を適用した注4)

\section{3. 結果及び考察}

\section{1 流量係数 $\alpha$ 低下の要因}

LES 計算により得られた開口部周辺の圧力場から、流量係数低 下についての検討を行なう。開口部通過時の全圧損失係数らは、全 圧差 $\Delta \mathrm{P}\left(=\mathrm{P}_{\mathrm{T}}-\mathrm{P}_{\mathrm{R}}\right)$ と開口を通過する気流の動圧 $\left(=\mathrm{P}_{\mathrm{N}}+\mathrm{P}_{\mathrm{t}}\right)$ の 比として定義する（式 9）。

$$
P_{T}-P_{R}=\zeta\left(P_{N}+P_{t}\right)
$$

既往研究 5) より、全圧損失係数 らは、 $\mathrm{P}_{\mathrm{R}}{ }^{*}$ に依存することなく、概称

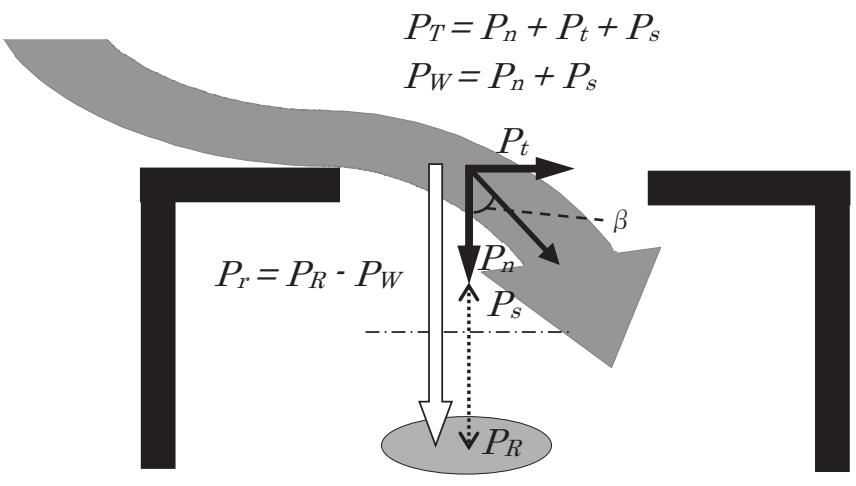

Fig. 1 Dynamic conditions around inflow opening

Table1 Parameters used in the Local dynamic similarity model

\begin{tabular}{cccc}
\hline \hline$P_{T}=P_{n}+P_{t}+P_{s}$ & $\cdots(1)$ & $P_{W}=P_{n}+P_{s}$ & $\cdots(2)$ \\
$P_{t}=P_{T}-P_{W}$ & $\cdots(3)$ & $P_{r}=P_{R}-P_{W}$ & $\cdots(4)$ \\
$P_{R}^{*}=\frac{P_{r}}{P_{t}}$ & $\cdots(5)$ & $\alpha=\sqrt{\frac{P_{n}}{\left|P_{r}\right|}}$ & $\cdots(6)$ \\
$\beta=\tan ^{-1} \sqrt{\frac{P_{t}}{P_{n}}}$ & $\cdots(7)$ & $Q=\alpha A \sqrt{\frac{2}{\rho}\left|P_{r}\right|}$ & $\cdots(8)$ \\
\hline \hline
\end{tabular}

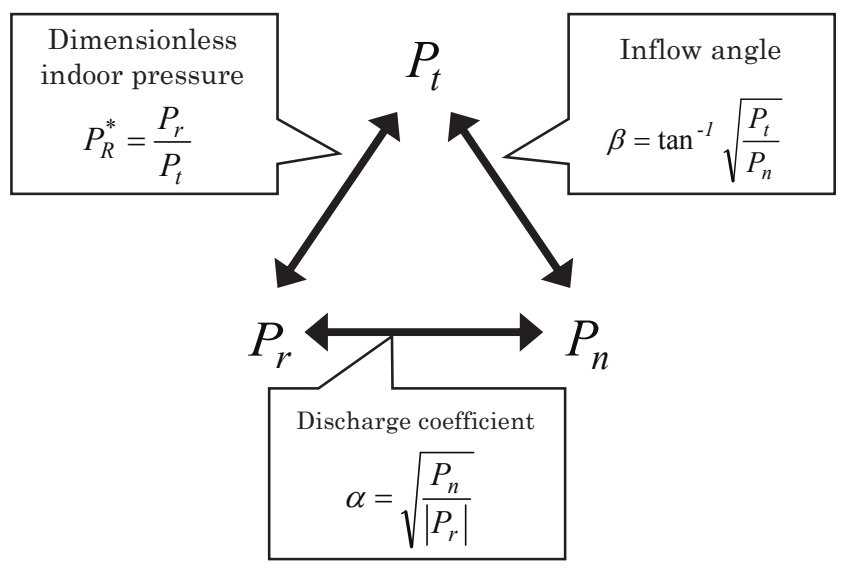

Fig. 2 Dynamic similarity of cross-ventilation

Opening size : $0.4 \times 0.8$

Thickness of Opening and

Chamber : 0.1

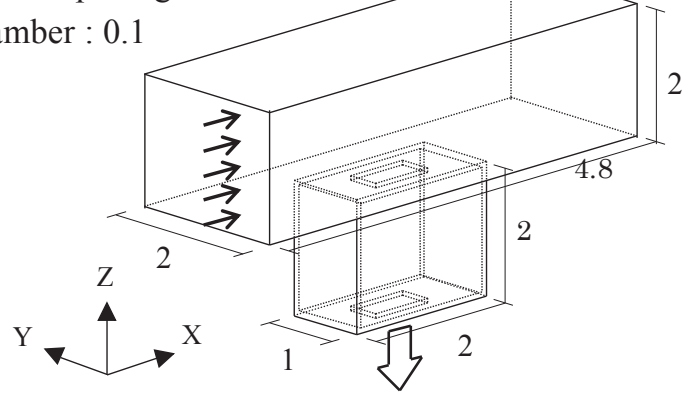

Fig. 3 Geometry of Model for LES 
一定とみなし得る。ここで、 $\mathrm{P}_{\mathrm{N}}$ と $\mathrm{P}_{\mathrm{t}}$ による寄与を分離すると、式 （10）のように表すことができる。

$P_{T}-P_{R}=P_{N}+(\zeta-1) P_{N}+P_{t}+(\zeta-1) P_{t}$

式（1）、式（2）より、開口部到達全圧 $\mathrm{P}_{\mathrm{T}}$ は、風圧力 $\mathrm{P}_{\mathrm{W}}$ と開口部 接線方向動圧 $\mathrm{P}_{\mathrm{t}}$ の和で表されるため、通風の換気駆動力 $\mathrm{P}_{\mathrm{W}}-\mathrm{P}_{\mathrm{R}}$ は、 式（11）のように示すことができる。

$P_{W}-P_{R}=P_{N}+(\zeta-1) P_{N}+(\zeta-1) P_{t}$

この両辺を $\mathrm{P}_{\mathrm{N}}$ で除すると、通風の圧力損失係数 $\mathrm{N}_{\mathrm{N}}$ は式 (12) のよ うに表される。

$\zeta_{N}=\frac{P_{W}-P_{R}}{P_{N}}=\zeta+(\zeta-1) \frac{P_{t}}{P_{N}}$

全圧損失係数らは概ね一定であることから、 $\mathrm{P}_{\mathrm{N}}$ に対して $\mathrm{P}_{\mathrm{t}}$ が相対 的に大きい状況下において右辺第 2 項が増大し、それに応じて $\zeta_{\mathrm{N}}$ が大きな值をとる。ら $\mathrm{N}$ と $\alpha$ は式（13）の関係があることから、こ れが $\mathrm{P}_{\mathrm{R}}{ }^{*}$ が 0 付近において、 $\alpha$ が低下寸る形式的要因となる。

$\zeta_{N}=\frac{1}{\alpha^{2}}$

\section{2 気流性状による考察}

Fig.4に $\mathrm{P}_{\mathrm{R}}{ }^{*}$ と $\alpha$ の関係を示す。 $\alpha$ の変化が最も顕著である Case1、 変化が緩やかで変動領域から一定領域に移行する Case4、 $\left|\mathrm{P}_{\mathrm{R}}{ }^{*}\right|>5$ で一定領域にある Case 7 にいて比較・検討を行う。比較を容易に するため、通風量が各ケースにおいて同一となるように計算結果の 変換を行う。室内压 $\mathrm{P}_{\mathrm{R}}$ を基準圧力として静压場をシフトすること で $\left(\mathrm{P}_{\mathrm{R}}=0\right)$ 、式（12）は式（14）のように表すことができる。

$\zeta_{N}=\frac{P_{W}}{P_{N}}$

さらに、式（2）を用いることで、式（14）は式（15）で表される。
$\zeta_{N}=1+\frac{P_{S}}{P_{N}}$

$\mathrm{P}_{\mathrm{N}}$ を基準圧力差として表現した $\mathrm{P}_{\mathrm{s}}$ を用いることで、式（15）は式 （16）のようになる。

$\zeta_{N}=1+P_{S}$

以上より、圧力損失の増加が開口部境界静圧の上昇に反映されるこ とになる。上記の変換を行なった開口部周辺の風速ベクトルと静圧 分布を Fig.5、Fig.6 に示す。Case1 では、風上側の空枠付近におい て、剥離により $\mathrm{P}_{\mathrm{s}}$ が負の領域が一部に存在するが、開口部接線方向 の気流が卓越し、開口部を通過する気流の大半が風下側の空枠に衝 突しているため、衝突域での静圧上昇が開口部全体に広がっている 様相が認められる。このため、気流が開口部を通過するためには、

Table2 Cases of LES simulation

\begin{tabular}{c|c|c|c}
\hline \hline & Air Flow Rate & & Air Flow Rate \\
\hline \hline Case 1 & 0.04 & Case 5 & 0.28 \\
\hline Case 2 & 0.08 & Case 6 & 0.40 \\
\hline Case 3 & 0.12 & Case 7 & 0.56 \\
\hline Case 4 & 0.20 & \multicolumn{2}{|c}{} \\
\hline \hline
\end{tabular}

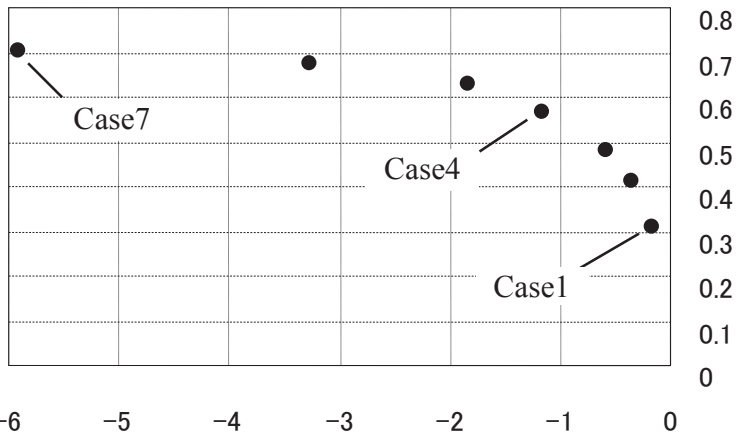

Fig. 4 Relation between discharge coefficient and dimensionless indoor pressure at inflow opening
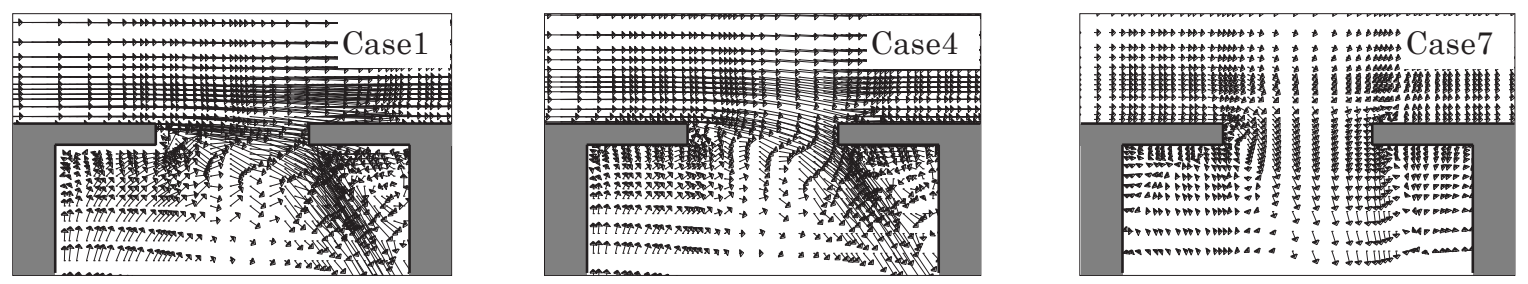

Fig. 5 Wind velocity vector distribution
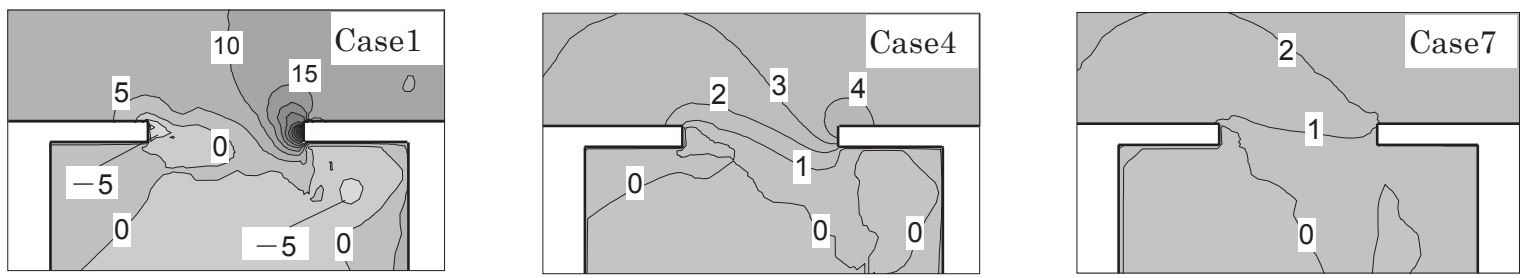

Fig. 6 Static pressure distribution 
この静圧上昇に対抗する必要があるので、通風量が減少し $\alpha$ は低下 する。Case4においても開口部接線方向の気流が卓越している状況 が見られるが、開口部の風上側を通過した気流については、滑らか に方向転換して室内に流入している。しかし、Case1 と同様に風下 側では空枠に衝突し、静圧上昇を引き起こしていることが確認され る。一方、Case7では開口部に対して概ね垂直に流入している様子 が伺える。このためCase1、4 で確認された風下側の空枠での衝突 はなく、開口部周辺における静圧上昇も見られない。以上より、通 風に抗する主要要因として、開口部周辺での静圧上昇が挙げられる ことが明らかになった。静圧上昇の要因解明が流量係数の予測に関 連して重要と考えられる。

\section{3 静圧上昇に関する要因解明}

\section{（1）仮想流管の概要}

開口部通過後の気流エネルギー変化の検討、圧力損失機構の解明 を目的として仮想流管による解析を行う。解析対象となる開口部を $100 \times 100$ の格子に等分割し、各格子の中心点から仮想粒子を風下 (チャンバー内部) 側に流し、その流跡線の包絡線から開口部を通 過する仮想流管の形状を推定する。仮想粒子がメッシュを通過する たびに、その地点での仮想流菅断面風量を算出し、開口部通過風量 との差が小さいことを確認した。仮想流菅内の各メッシュにおける 全圧・動圧・静圧は各メッシュ通過風量による重みつけを行い、仮 想流菅内の重み付け平均值から、圧力変化の様相の把握を試みた。

\section{(2) $\left|P_{R}{ }^{*}\right|>1$ における圧力変化の解明}

Fig.7 に、 $\left|\mathrm{P}_{\mathrm{R}}{ }^{*}\right|>1$ の領域にある Case4 から Case7 について、 横軸を開口面からの距離として、流管内での圧力と流断面積の変化 の様相を示す。ただし、各ケース間における比較を容易にするため、 開口部到達時の動圧 $\mathrm{P}_{\mathrm{N}}+\mathrm{P}_{\mathrm{t}}$ を基準圧力差、室内圧 $\mathrm{P}_{\mathrm{R}}$ を基準圧力と する。この変換により、式（9）から開口到達全圧 $\mathrm{P}_{\mathrm{T}}$ は全圧損失係 数とを表すこととなる。開口部通過時に流管形状の変化とともに断 面積が縮小していることから、全てのケースについて縮流が生じて いることが確認される。さらに、この縮流に伴う $\mathrm{U}_{\mathrm{N}}$ の急加速によ り、急激な動圧の上昇と静圧の低下が同時に生じていることから、 静圧・動圧間でのエネルギー交換が行われていることが明らかであ る。従来、開口部通過時の縮流におけるエネルギー変化は、このよ うな動圧・静圧間での可逆的な相変化が主体とみなされてきたが、 開口部通過時に若干の全圧損失が生じていることがわかった。

\section{（3）乱流エネルギー生産項による検討}

ここで全圧損失の原因解明のため、Case 4 Case7 において推定 した仮想流管形状を、チャンバー開口中心鉛直断面における乱流エ ネルギーの生産項 $\mathrm{P}_{\mathrm{k}}$ (但し、Subgrid スケール Reynolds 応力の影 響は無視）の空間分布上に重㱛て示す（Fig.8）。開口近傍の流管内 部に大きな $\mathrm{P}_{\mathrm{k}}$ の分布が確認できることから、これが、圧力変化の検 討にて確認された全圧損失の要因と考えられる。つまり、開口部静 圧は開口流入直後の縮流時に一部が乱流エネルギー生産として消失 し(全圧損失)、一部が動圧に転換、さらに縮流後には、開口部静圧 は室内平均静圧まで低下し、Fig.9 に示すように室内一様場に放出 される噴流として室内に拡散しているとみなすことができることが 明らかとなった。
Pressure [-]

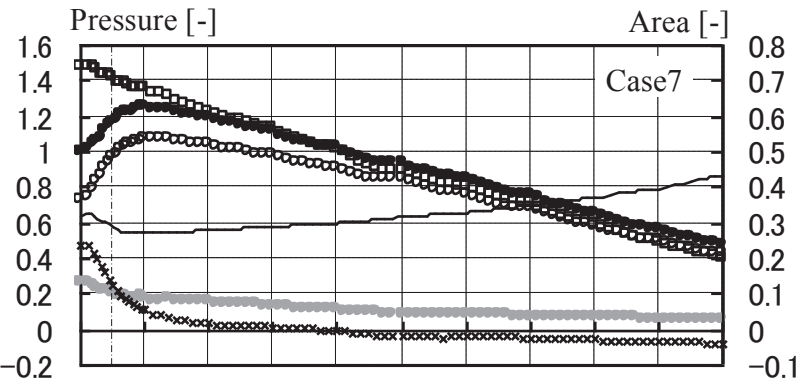

$\begin{array}{lllllllllll}0 & 0.2 & 0.4 & 0.6 & 0.8 & 1 & 1.2 & 1.4 & 1.6 & 1.8 & 2\end{array}$ Distance from opening [-]

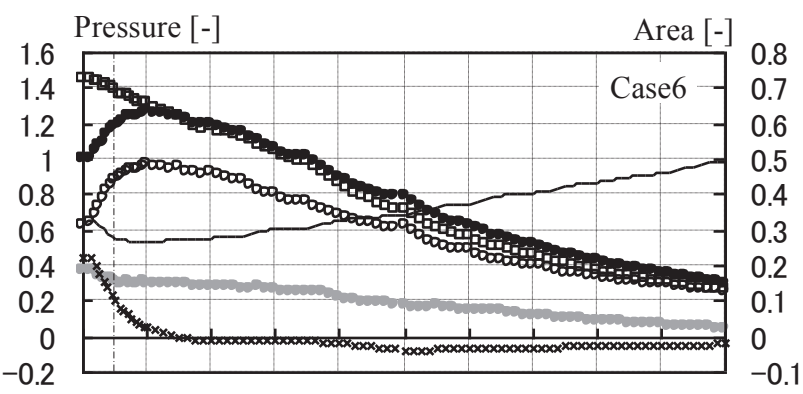

$\begin{array}{lllllllllll}0 & 0.2 & 0.4 & 0.6 & 0.8 & 1 & 1.2 & 1.4 & 1.6 & 1.8 & 2\end{array}$ Distance from opening [-]

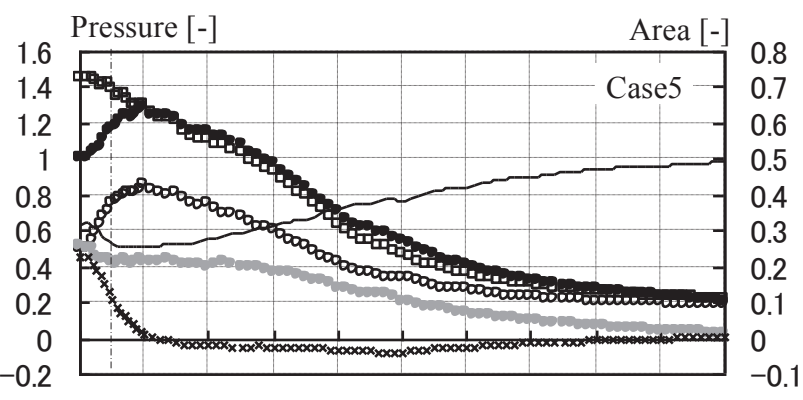

$\begin{array}{lllllllllll}0 & 0.2 & 0.4 & 0.6 & 0.8 & 1 & 1.2 & 1.4 & 1.6 & 1.8 & 2\end{array}$ Distance from opening [-]

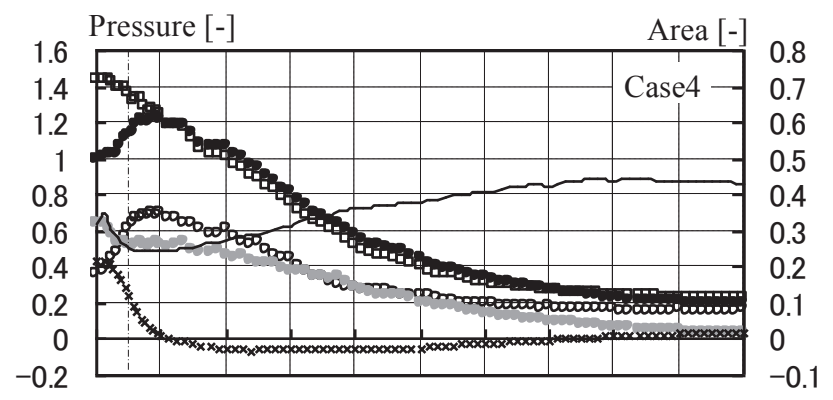

$\begin{array}{lllllllllll}0 & 0.2 & 0.4 & 0.6 & 0.8 & 1 & 1.2 & 1.4 & 1.6 & 1.8 & 2\end{array}$ Distance from opening [-]
$\square$ Total Pressure • Dynamic Pressure
$\times$ Static Pressure $\bigcirc \mathrm{P}_{\mathrm{N}} \circ \mathrm{P}_{\mathrm{t}}-$ Area

Fig. 7 Transition of pressure and flow cross-sectional area in stream tube (Case4 - Case7)

\section{(4) $\left|P_{R}^{*}\right|<1$ における圧力変化の解明}

Fig.10 に $\left|\mathrm{P}_{\mathrm{R}}{ }^{*}\right|<1$ の領域にある Case1 から Case3 について、流 管内での圧力と流断面積の変化の様相を示す。 3 ケースの比較によ り、| $\mathrm{P}_{\mathrm{R}}{ }^{*} \mid$ が 0 に近づくほど、つまり、 $\mathrm{P}_{\mathrm{N}}$ に対して $\mathrm{P}_{\mathrm{t}}$ が相対的に大 

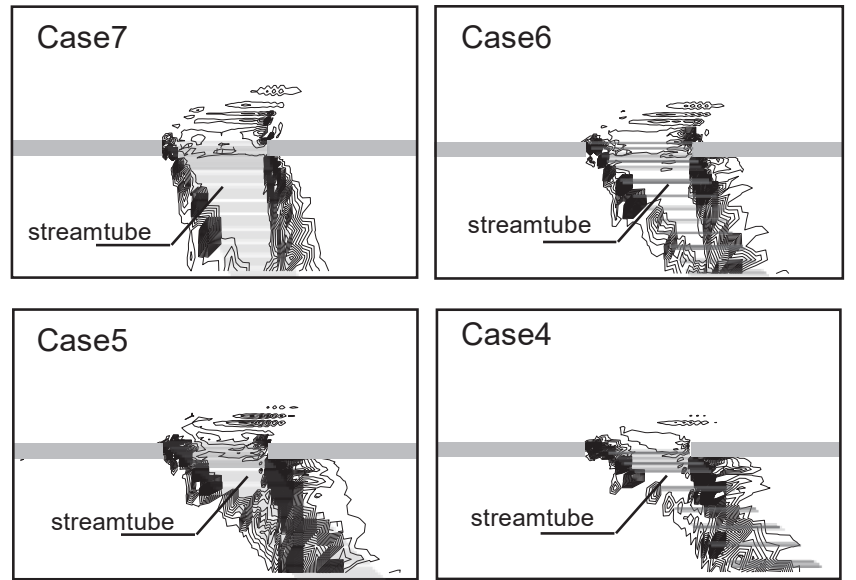

Fig. 8 Shape of stream tube and dirstribution of turbulence kinetic energy (Case4 Case7)

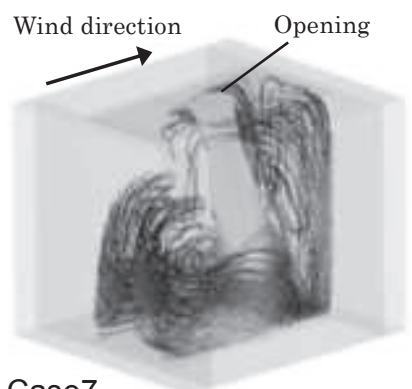

\section{Case7}

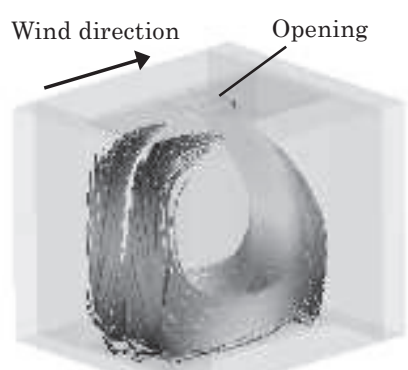

Case5
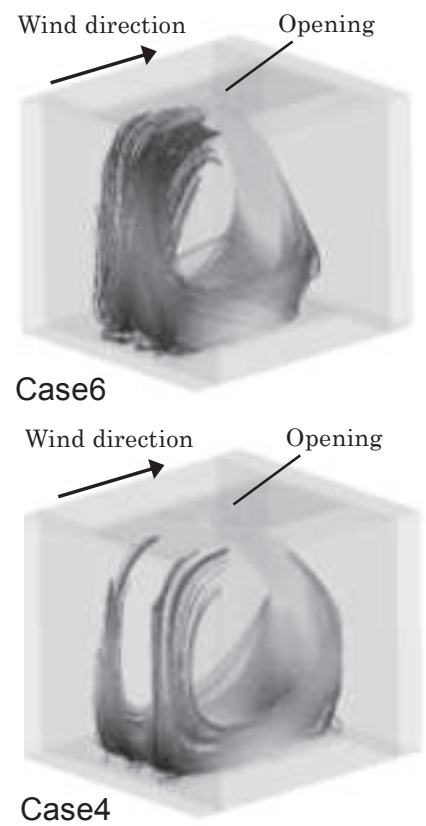

Fig. 9 Streamline of airflow (Case4 Case7)

きい状況下において、開口部通過段階で動圧の低下と静圧の上昇が 確認でき、Fig.7 の結果と異なる様相を示している。しかし、全圧 損失については同様に認められる。開口部通過時の動圧低下は、 $\mathrm{P}_{\mathrm{t}}$ の低下に起因すると考えられる。すなわち、Fig.6 に示す空枠との 衝突により、接線方向の動圧の一部が方向転換によって生じる法線 方向の動圧と静圧上昇にエネルギー変換される。Fig.11 に仮想流管 形状と乱流エネルギー生産項 $\mathrm{P}_{\mathrm{k}}$ の空間分布を示し、Fig.12に開口 部通過気流の流線を示す。開口部を通過した後は、接線方向動圧に よる寄与を加えて増大した静圧は、Case4 以降と同様、縮流による 動圧上昇と乱流エネルギー生産に費やされていると判断できる。

\section{4. まとめ}

本研究では、通風量算出に必要な流量係数が風向角により低下寸 る要因解明のために、開口部通過時におけるエネルギー変化・圧力 損失について LES により検討を行い、以下の知見を得た注 5)。

1). 開口部周辺の圧力に関する式の展開より流量係数 $\alpha$ が低下寸
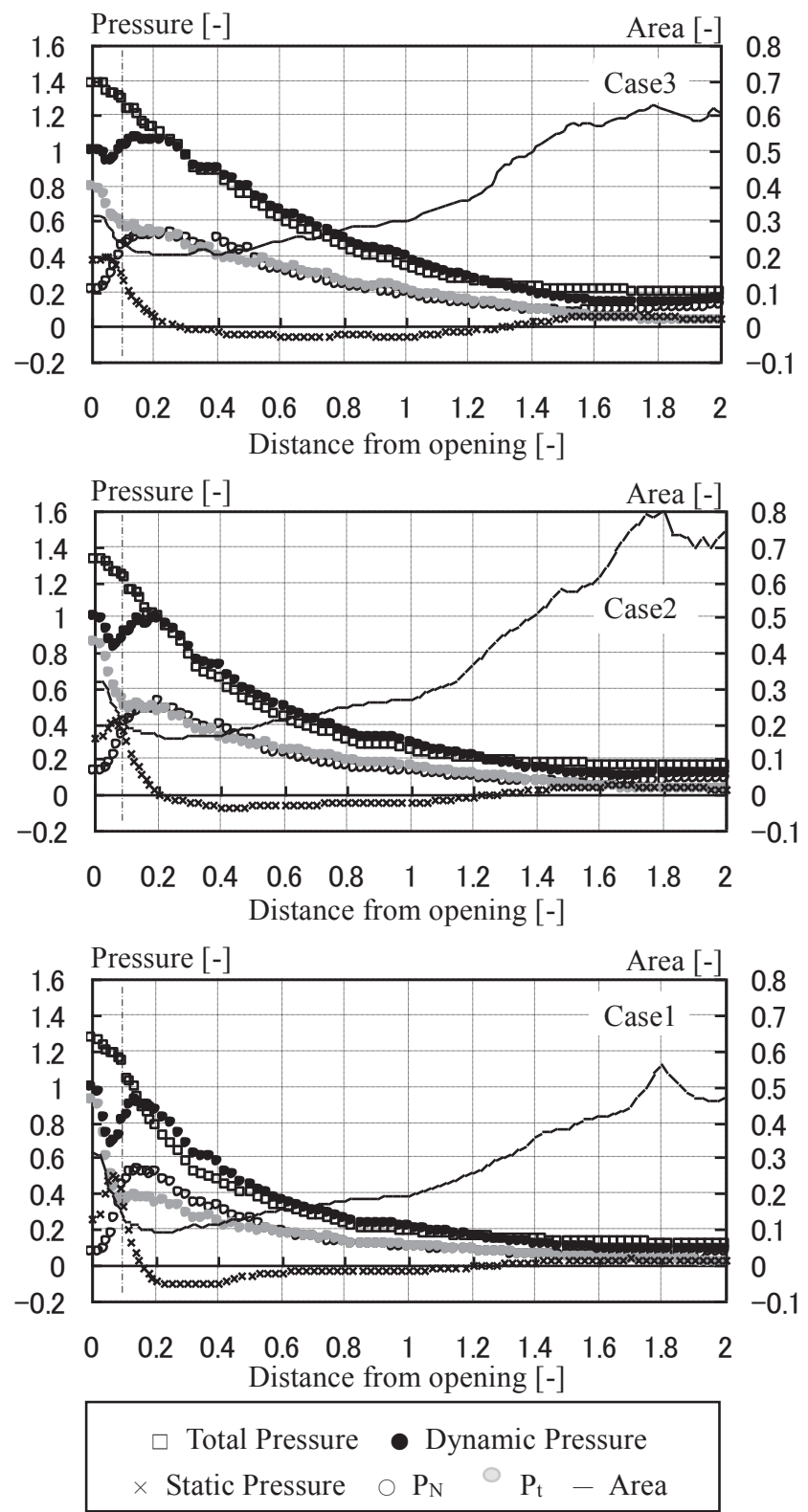

Fig. 10 Transition of pressure and flow cross-sectional area in stream tube (Case1 - Case3)
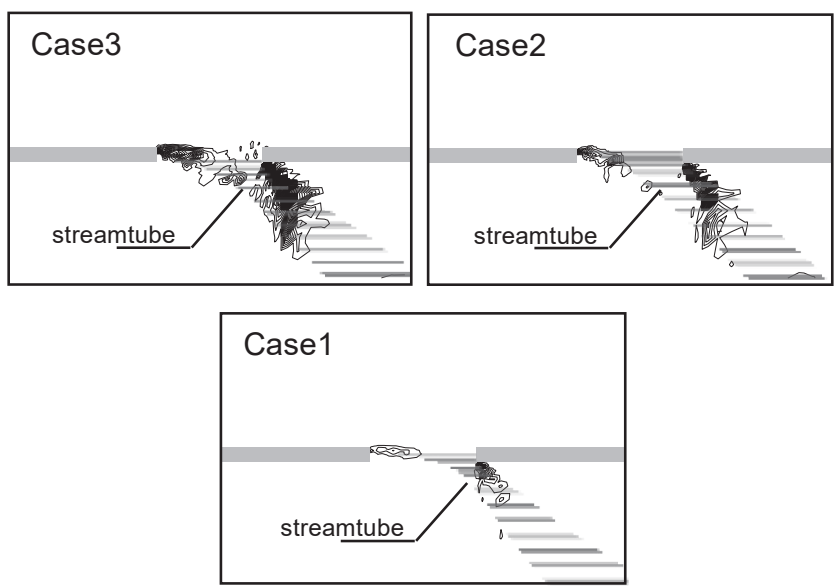

Fig. 11 Shape of stream tube and dirstribution of turbulence kinetic energy (Case1 Case3) 
る要因について考察し、開口部接線方向動圧の寄与が重要で ある事を示した。

2). 開口部接線方動圧が換気駆動力に対して相対的に大きい領域 においては、|$\left|\mathrm{P}_{\mathrm{R}}{ }^{*}\right|$ が小さくなるにつれ、開口部接線方向の 気流が開口端部に衝突して生じる開口内静圧上昇が大きくな り、この静圧上昇が流量係数低下の要因として挙げられるこ とが明らかとなった。

3). 開口部通過時の圧力変化について、仮想流管を用いた詳細検 討を実施したところ、全てのケースにおいて縮流が見られ、 縮流時には静圧・動圧間での可逆的なエネルギー交換が行わ れていることを確認した。

4). 仮想流管による検討の結果、Case4 から Case7 においては、 縮流時に動圧上昇と静圧低下が同時に生じていることが確認 されたが、Case1から Case3においては、縮流時に動圧低下 と静圧上昇が同時に生じていることが明らかとなった。これ は、開口部接線方向動圧が空枠への衝突により、開口部法線 方向動圧一の転換と静圧上昇に使用されるためである。

5). 仮想流管による分析により、全ての Case において、縮流時 に全圧損失が見られた。この理由として、流管内の開口部付 近に乱流エネルギー生産項 $\mathrm{P}_{\mathrm{k}}$ の大きな分布が見られること から、開口部通過時に静圧の一部が乱流エネルギー生産に費 やされるためであることが明らかとなった。

\section{謝辞}

本研究の遂行にあたり、当時東京理科大学大学院生の中山文宏氏に は多大なるご協力を頂きました。ここに記して感謝いたします。

\section{記号}

$\mathrm{P}_{\mathrm{T}} \quad$ 全压

$\mathrm{P}_{\mathrm{t}} \quad$ 開口部（壁面）接線方向の動圧

$\mathrm{P}_{\mathrm{n}} \quad$ 開口部（壁面）法線方向の動圧

$\mathrm{P}_{\mathrm{s}} \quad$ 静压

$\mathrm{P}_{\mathrm{W}}$ 風圧

$\mathrm{P}_{\mathrm{R}} \quad$ 室内圧

$\mathrm{P}_{\mathrm{r}} \quad$ 基準化室内圧 $\left(=\mathrm{P}_{\mathrm{R}}-\mathrm{P}_{\mathrm{W}}\right.$ 、換気駆動力 $)$

$\mathrm{P}_{\mathrm{R}}{ }^{*} \quad$ 無次元室内圧 $\left(=\mathrm{P}_{\mathrm{r}} / \mathrm{P}_{\mathrm{t}}\right)$

$\alpha \quad$ 流量係数

$\beta \quad$ 流入角

Q 通風量

A 開口面積

$\rho$ 空気密度

$\mathrm{U}_{\mathrm{N}} \quad$ 開口部法線方向の風速

$\mathrm{U}$ 風洞主流方向の風速

$\mathrm{k} \quad$ 乱流エネルギー

$\mathrm{P}_{\mathrm{k}} \quad$ 乱流エネルギー生産項

\section{参考文献}

1) Nakayama, F., Kurabuchi, T., Ohba, M., Endo, T. and Akamine, Y.: A Study on Evaluation of Cross-Ventilation Performance of Openings Part 9 A Study on Mechanism to Change Discharge coefficient of Inflow Openings, Summaries of Technical Papers of Annual Meeting, Architectural Institute of Japan, Environmental Engineering-II, pp.827-828, 2003.7

中山文宏, 倉渕隆, 大場正昭, 遠藤智行, 赤嶺嘉彦: 開口部の通風性能 評価に関する研究 その 9 流入開口部の流量係数変化のメカニズムに 関する研究, 日本建築学会大会学術講演梗概集, D-2, pp. 827-828, 2003. 7
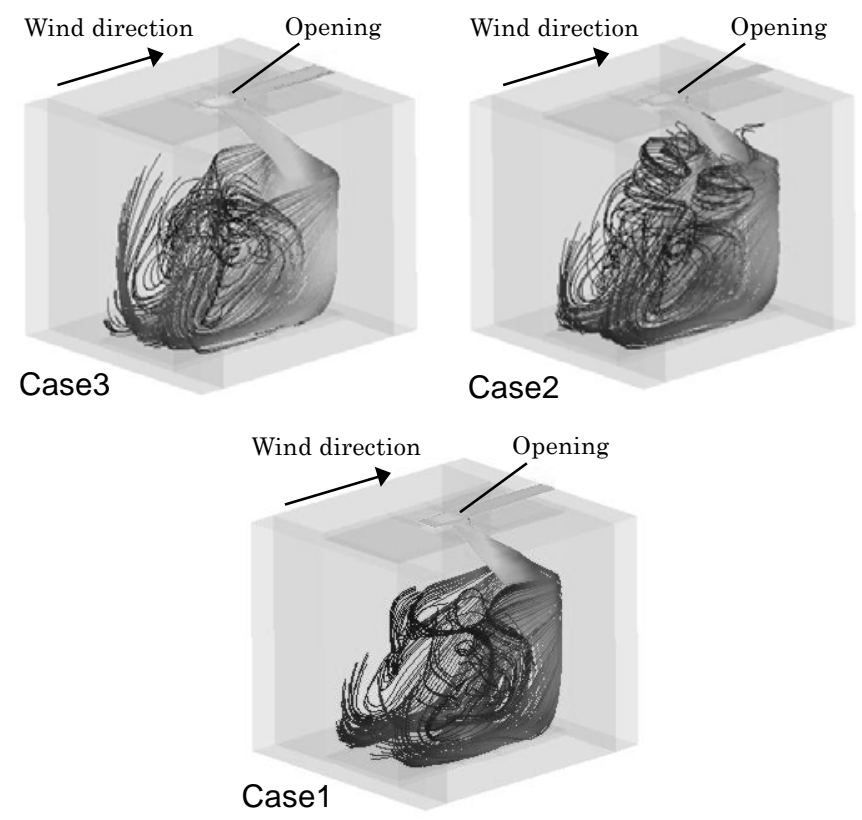

Fig. 12 Streamline of airflow (Case1 Case3)

2) Habara, H., Narumi, D., Kobayashi, S., Simoda, Y. and Mizuno, M.: Development of a Method to Estimate Indoor Thermal Condition and Air Conditioning Energy Consumption in Residential House Using Natural Ventilation, Journal of Environmental Engineering (Transactions of AIJ), No. 582, pp. 107-114, 2004. 8 (in Japanese) 羽原宏美, 鳴海大典, 小林誠治, 下田吉之, 水野稔: 自然通風を行う住 宅の室内温熱環境および空調エネルギー消費予測手法の開発, 日本建 築学会環境系論文集, 第 582 号, pp. 107-114, 2004. 8

3) Habara, H., Narumi, D., Shimoda, Y. and Mizuno, M.: Influence of Temperature, Radiation and Airflow Varied by Buildings on Cross Ventilation and Cooling Energy Consumption in a Residential House, Journal of Environmental Engineering (Transactions of AIJ), No. 613, pp. 103-110, 2007. 3 (in Japanese)

羽原宏美, 鳴海大典, 下田吉之, 水野稔: 周辺建物群による外気温条件, 放射条件, 風条件の変化が住宅における自然通風利用および冷房エネ ルギー消費に与える影響, 日本建築学会環境系論文集, 第 613 号, pp. 103-110, 2007. 3

4) Kurabuchi, T., Ohba, M., Iwabuchi, T. and Shimada, T.: Verification and Streamtube Analysis of Simulated Result of Airflow of a Cross-ventilated Building for Normal Wind Angle Case, Analysis of Airflow of Cross-ventilated Buildings Based on LES and Wind Tunnel Experiment (Part1), Journal of Environmental Engineering (Transactions of AIJ), No. 561, pp. 47-52, 2002. 11 (in Japanese)

倉㴊隆, 大場正昭, 岩㴊拓志, 島田朋裕：風向正面の場合の通風気流に 関する予測精度検証と流管分析 LES と風洞実験による建物通風気流 構造の解明に関する研究（第 1 報）, 日本建築学会環境系論文集, 第 561 号, pp. 47-52, 2002. 11

5) Kurabuchi, T., Ohba, M. and Endo, T.: Verification and Streamtube Analysis of Simulated Results of Airflow of a Cross-ventilated Buildings for Various Wind Incident Angles, Analysis of Airflow of Cross-ventilated Buildings Based on LES and Wind Tunnel Experiment (Part2), Journal of Environmental Engineering (Transactions of AIJ), No. 591, pp. 7-13, 2005. 5 (in Japanese) 倉㴊隆, 大場正昭, 遠藤智行: 様々な風向角度の場合の通風気流に関 する予測精度検証と流管分析 LES と風洞実験による建物通風気流構 造の解明に関する研究 (第 2 報), 日本建築学会環境系論文集, 第 591 号, pp. 7-13, 2005. 5

6) Endo, T., Kurabuchi, T., Ishii, M., Komamura, K., Maruta, E. and Sawachi, T.: Study on the Numerical Predictive Accuracy of Wind Pressure Distribution and Air Flow Characteristics -Part 1 
Optimization of Turbulence Models for Practical Use; Part 2 Prediction Accuracy of Wind Pressure Distribution of Various Shaped Buildings, The International Journal of Ventilation, Vol. 4 No. 3, pp. 269-284, 2005. 12

7) Ishihara, M.: Kenchikukankisekkei (Design of ventilation), Asakura Publishing, 1969 (in Japanese) 石原正雄，建築換気設計，朝倉書店, 1969

8) Kotani, H. and Yamanaka, T.: Prediction of Inflow Direction at Large Opening of Cross Ventilated Apartment Building, Journal of Environmental Engineering (Transactions of AIJ), No. 609, pp. 39-45, 2006. 11

甲谷寿史, 山中俊夫：集合住宅の大開口における通風気流の流入角予 測法，日本建築学会環境系論文集，第 609 号, pp. 39-45, 2006. 11

9) Katsuta, C. and Sekine, T.: Experimental Study on Ventilation by The Opening of Wall Surface, Transactions of the Architectural Institute of Japan, No. 68, pp. 116-120, 1961. 6 (in Japanese) 勝田千利，関根毅：建築物壁面開口部による換気に関する実験的研究 （その 1）特に開口部の圧力損失係数と風圧係数について, 日本建築学 会論文報告集，第 68 号，pp. 116-120, 1961. 6

10) Kiyota, N. and Sekine, T.: Experimental Study on Pressure Loss at the Opening of Wall Surface (PartII), Journal of Architecture, Planning and Environmental Engineering (Transactions of AIJ), No. 398, pp. 47-57, 1989. 4 (in Japanese)

清田誠良, 関根毅, 模型壁面の開口部圧力損失に関する実験的研究 (続 報），日本建築学会計画系論文報告集，第 398 号，pp. 47-57, 1989. 4

11) Murakami, S., Kato, S., Akabayashi, S. and Mizutani, K.: Wind Tunnel Test on Velocity Pressure Field of Cross-Ventilation with Open Windows, ASHRAE Transactions, Vol. 97, pp. 525-538, 1991

12) Kobayashi, T., Kotani, H., Yamanaka, T., Sagara, K., Momoi, Y. and Asai, K.: Wind Tunnel Test and Numerical Simulation for Pressure and Velocity Field around Cross-ventilated Building, Journal of Environmental Engineering (Transactions of AIJ), Vol. 76, No. 662, pp. 385-392, 2011. 4

小林知広, 甲谷寿史, 山中俊夫, 相良和伸, 桃井良尚, 浅井香里: 通風 時の建物周辺の圧力場及び風速場に関する風洞実験と数值解析, 日本 建築学会環境系論文集，第 76 巻，第 662 号, pp. 385-392, 2011. 4

13) Kobayashi, T., Kotani, K., Yamanaka, T., Sagara, K., Momoi, Y. and Asai, K.: A Fundamental Study on Cross-ventilation Rate and Airflow Characteristic Inside Flow path through a Room, Journal of Environmental Engineering (Transactions of AIJ), Vol. 76, No. 665, pp. 609-616, 2011. 7

小林知広，甲谷寿史，山中俊夫，相良和伸，桃井良尚，浅井香里：通風 時の換気量及び室内を通過する気流性状に関する基礎的研究, 日本建 築学会環境系論文集, 第 76 巻, 第 665 号, pp. 609-616, 2011. 7

14) Kurabuchi, T., Ohba, M., Endo, T. and Akamine, Y.: Local Dynamic Similarity Concept and Underlying Wind Tunnel Tests, Prediction Accuracy of Flow Rate of Cross-ventilated Buildings (Part1), Journal of Environmental Engineering (Transactions of AIJ), No. 607, pp. 37-41, 2006. 9 (in Japanese)

倉㴊隆，大場正昭，遠藤智行，赤嶺嘉彦：局所相似モデルの概念と風洞 実験による検証 通風時の換気量予測法に関する研究（第 1 報），日本 建築学会環境系論文集, 第 607 号, pp. 37-41, 2006.9

15) Ohba, M., Kurabuchi, T., Goto, T., Endo, T., Akamine, Y. and Nonaka, T.: Investigation on Applicability of Local Dynamic Similarity Model for Inflow Openings, Prediction Accuracy of Flow Rate of Cross-ventilated Buildings (Part2), Journal of Environmental Engineering (Transactions of AIJ), No. 617, pp. 25-30, 2007. 7 (in Japanese)

大場正昭，倉㴊隆，後藤伴延，遠藤智行，赤嶺嘉彦，野中俊宏：流入開 口部における局所相似モデルの適用性に関する検討 通風時の換気量 予測法に関寸る研究（第 2 報），日本建築学会環境系論文集，第 617 号, pp. 25-30, 2007. 7

16) Endo, T., Kurabuchi, T., Akamine, Y., Ohba, M. and Kamata, M.: Development of the Test Procedure and the Database of Cross-ventilation Characteristic of Various Openings, Journal of Environmental Engineering (Transactions of AIJ), Vol. 74, No. 646, pp. 1315-1320, 2009. 12 (in Japanese)

遠藤智行, 倉㴊隆, 赤嶺嘉彦, 大場正昭, 鎌田元康: 流入開口部通気特 性評価法の開発及び通気特性データベースの構築, 日本建築学会環境 系論文集，第 74 巻，第 646 号, pp. 1315-1320, 2009. 12

17) Ohba, M., Kurabuchi, T., Endo, T., Akamine, Y., Kamata, M. and kurahashi, A.: Local Dynamic Similarity Model of Cross-Ventilation Part2-Application of Local Dynamic Similarity Model, The International Journal of Ventilation, Vol. 2, No. 4, pp. 383-393, 2004. 3

注1）本論文は 2003 年度日本建築学会学術講演会において発表した論文 1) に基づいて加筆・修正したものである。

注2）通風性能評価実験 16) における実験装置概要図（下図）のナイフエッジ が先端に取り付けられた仮床より上部空間（以降、風洞部と呼ぶ）と 開口部、チャンバーを Fig.3 のように模擬した空間を計算の対象とし ている。

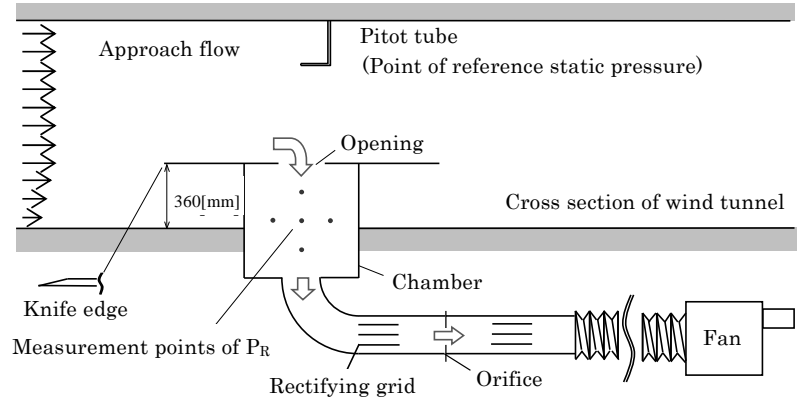

注3）既往研究 5)のストックデータを加工した流入プロファイル及び本研究 にて用いる範囲（図中の灰色部）は下図のとおりである。既往研究 5) におけるアプローチフローは代表風速 $7 \mathrm{~m} / \mathrm{s}$ 、代表長さ $0.15 \mathrm{~m}$ を想定 して作成されているため、本研究においても、風洞流入部の代表速度

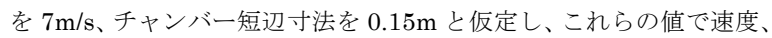
長さを無次元化して検討を行なった。なお、全ての caseにおいてレイ ノルズ数は約 69953 で一定である。
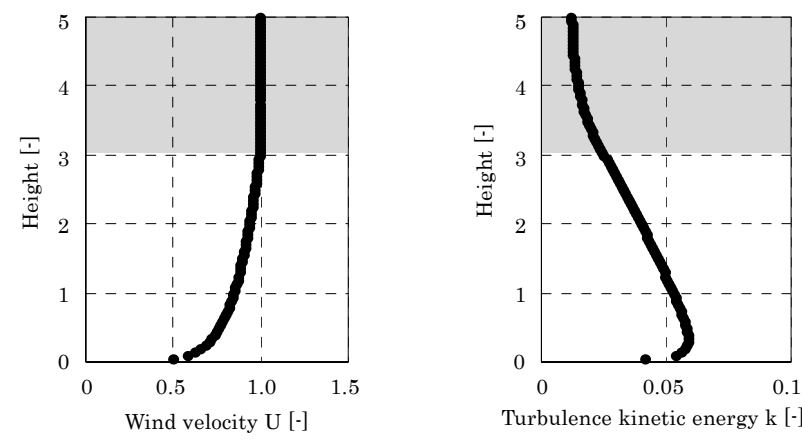

注4）計算は解が概ね定常に達した後、20 万ステップの計算を行い、結果を 統計処理した。計算条件及びメッシュの妥当性を判断するために、既 往研究 16)に示寸風洞実験により取得した開口部周辺の静圧分布と比較 し、良好な結果が得られていることを事前に確認した（下図）
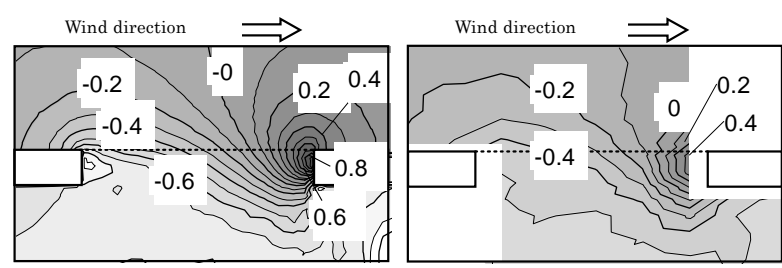

Static pressure distribution (Left : LES、Right : Wind tunnel experiment)

注5）仮想流管による検討については、対象となる室と開口部との大きさの 比や開口部形状等によって、変化することも考えられることから、今 後も引き続き、種々のケースにて検討を行い、知見を重ねていく必要 があると考えられる。 


\title{
A STUDY ON PRESSURE LOSS MECHANISM IN THE INFLOW OPENINGS OF CROSS-VENTILATION
}

\section{Tomoyuki ENDO*, Takashi KURABUCHI**, Masaaki OHBA*** and Yoshihiko AKAMINE ****}

\author{
* Assoc. Prof., Kanto Gakuin University, Dr.Eng. \\ ** Prof., Tokyo University of Science, Dr.Eng. \\ *** Emeritus Prof., Tokyo Polytechnic University, Dr.Eng. \\ **** Senior Research Officer, National Institute for Land and Infrastructure Management, Dr.Eng.
}

In recent years, cross-ventilation is actively used in the mid-season and at night and in the early morning in summer as a countermeasure toward global warming. This aims to gain energy-saving effect of buildings' cooling down and thermal environmental improvements by using of cross-ventilation. Lately, some studies calculated energy-saving effects of cross-ventilation.

In the calculation of cross-ventilation rate, discharge coefficient is known to change with the wind direction as the same as the wind pressure coefficient is. However, most of the studies calculating the energy-saving effects fixed the discharge coefficient. This means that the precision of these results has still room of examination.

To this problem, the authors offered the local dynamic similarity model based on the dynamic conditions of inflow openings, and successfully calculated the discharge coefficient changes through the pressure conditions at the openings. This model uses a ventilation driving force, which is the difference between the wind pressure and the indoor pressure, and a dynamic pressure in tangential direction at the opening. The proportion of these two parameters is expressed as dimensionless indoor pressure $\left(\mathrm{PR}^{*}\right)$, and the discharge coefficient and the inflow angle are decided by $\mathrm{PR}^{*}$.

This study firstly examined the discharge coefficient changing mechanism on different $\mathrm{PR}$ * conditions with $\mathrm{CFD}$ (Large Eddy Simulation). The results show that total pressure loss coefficient is steady over all regardless of PR* differences, and that the static pressures increase widely by airflow crashes to window flames when dynamic pressure in tangential direction at the opening excels. The results also show that the cross-ventilation rate and the discharge coefficient decrease because airflows counteract from the static pressure increases to go through the openings.

Secondary, this study conducted an examination with virtual stream tube to reveal the ventilation energy variation and the pressure loss mechanism after airflow passing through the openings. In the results, the dynamic pressure in tangential direction converted to the dynamic pressure in normal direction and the static pressure decrease appeared in the area where the dynamic pressure in tangential direction at the opening is relatively large (around the area where $\mathrm{PR}^{*}$ is close to zero), and the dynamic pressure increase by vena contracta and static pressure decrease also appeared. The results shows that the turbulent kinetic energy production is one of the considerable factors of total pressure decrease. 